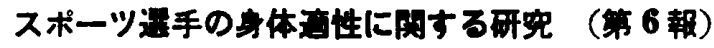 一持久性テストの湌㣥一}

その 4 持久走 $1500 \mathrm{~m}$ テストの妥当性について 東京都站世亚信工業高校付属中学校

$$
\text { 日等本体育大学 } \begin{array}{r}
\text { O中 村 越 智 三王 } \\
\text { 知 }
\end{array}
$$

(I) 研究の意竬，目的

われわれは身体適性検查法のうち，特に機能及び運動 能力の湘定方法に再検討する必要があるものとして，今 回は持久性テストの検討のうち全身性持久力テストとし て $1500 \mathrm{~m}$ 走をとりあげてみた. C. H. McCloy による と「200m 以上の距離の疾走検查は疾走速度が一定に保 持されるならば，適切な循環呼吸系の持久性の検査とな る」，といら説に対してわが国では，全身性持久力テス

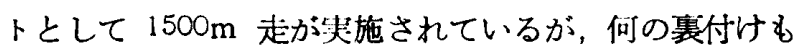
ないのでもつと少ない距離では持久性テストとして妥当 でないのだろらかと哮た．そこで今回はスピードを一 尖にすることはできなからたが, $1500 \mathrm{~m}$ 走と $800 \mathrm{~m}$ 走 と H.S.T. 得点との各種相阅々係を算出し, 統計兴似 少法により此較検討し，測定方法を一屏明確にすること を目的とした。

\section{(II) 研究の方法}

(1) 測定方法及び内容

○ $1500 \mathrm{~m}$ 走 「スポーツテスト」荘項 174 頁参留

○ $800 \mathrm{~m}$ 走 $1500 \mathrm{~m}$ 赴準ずる.

O H.S.T. 得点〜「スポーツテスト」熙項 77 貢参监 公式 $=-$ 運動時閉 $($ 秒 $) \times 100$

(2) 被歌者

○日本体青大学各運動部選手上り聂優秀選手 12 名

(3) 測定年月日及び場所

○昭和 40 年 7月 13 日 7 月 28 日

川來体有人兴トレーニングセンター及でグラリン ト

\section{(III) 結果の考察}

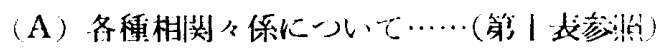

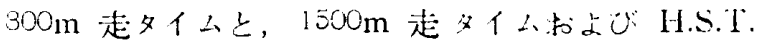

\begin{tabular}{|c|c|c|}
\hline & 相阅係数 & 有意性検定 \\
\hline 800 m走と $1500 \mathrm{~m}$ 走 & 0.954 & $0.1 \%$ K年157有意てある \\
\hline $800 \mathrm{~m}$ 走とH.S.T. 得卓 & 0.203 & 有意新めらんす” \\
\hline $1500 \mathrm{~m}$ 走とH.S.T得卓 & 0.354 & . \\
\hline
\end{tabular}

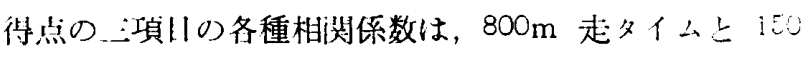

第I表 相関係数有意性梌定表

$\mathrm{m}$ 走タイムとの間には $(0.954)$ となり，0.1\%水淮に て有意性が認められ, $800 \mathrm{~m}$ 走タイムと H.S.T. 得点は (0.203)，1500m 走タイムと H.S.T. 得点との間にも, (0.354) といずれも有意性は認められなかつた。 この研 究に括いては，全身性持久力テスト（持久走テスト） $1500 \mathrm{~m}$ 走タイムと, $800 \mathrm{~m}$ 走タイムとの間には，かな り高い相関々俰があると認められる。このことは，持久 走テストとして長い距離の $1500 \mathrm{~m}$ 走を害施しないで, $800 \mathrm{~m}$ 走でもよいのではないかと考えられる.

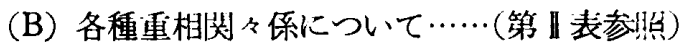

各種重相関々係をみると，第『表の通り，走力に刘与 る走力と H.S.T. 得点とを組み合わせた関係を見ると问 い重相関々保が的狆た。

以上の絬颗から，全身性持久力テストとして，文部省

\begin{tabular}{|c|c|c|}
\hline & 重相闻係数 & 有意性换定 \\
\hline $800 \mathrm{~m}$ : $1500 \mathrm{~m}$ 走, H.S.T得卓 & 0.964 & 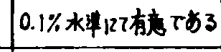 \\
\hline $1500 \mathrm{mt} ; 800 \mathrm{~m}$ 走, H.S.T.值 & 0.967 & $0.1 \%$ 水装12て桍てか3 \\
\hline HS.T.得等; $800 \mathrm{~m}$ 走，1500 m走 & 0.567 & 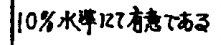 \\
\hline
\end{tabular}
スボーッテスト戊施货項では, $1500 \mathrm{~m}$ 走といらことに

第 II 表 重相関係数及び有意性検定敖

なつているが，持久性テストの簡素化といら点からみる と, 可及的短かい距離で実施できる $800 \mathrm{~m}$ 走の方が, より便利であるばかりでなく，むつと現在より広範囲に 渡つて，この持久走テストが行なわれるるのと思う。

今回の測定結果から，持久走テストとして $1500 \mathrm{~m}$ 走 でなく，800m 走でもよいといら䋐がでたのである

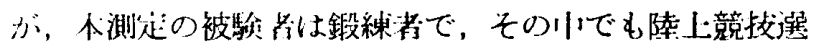
チが多いため，この上らな絬果になつたかめしれない。 そこで次の研究淉題として, 被験者の撰定治，おょび McCloy のいら $800 \mathrm{~m}$ 走より短加い $400 \mathrm{~m}$ 走, $200 \mathrm{~m}$ 走等に一いて，もつと深く追究していきたい。 